\title{
Yeast-like fungi isolated in students
}

\author{
ANNA BIEDUNKIEWICZ \\ Department of Mycology, University of Warmia and Mazury in Olsztyn \\ Oczapowskiego 1A, PL-10-957 Olsztyn, alibi@uwm.edu.pl
}

Biedunkiewicz A.: Yeast-like fungi isolated in students. Acta Mycol. 42 (1):141-149, 2007.

The occurrence of yeast-like fungi in the most important infection portals of the respiratory system in 200 randomly chosen students of biology and veterinary medicine was examined. The students come into direct contact with plants and animals that may be colonised by fungi belonging to various systematic groups.

Nine species of yeast-like fungi, including 7 species determined in the biologists, were recorded in the subjects. Candida tropicalis and C.albicans were the most frequently isolated fungi. The greatest number of fungi was isolated from the oral cavity (124 isolates), fewer from the throat (79 isolates), and the smallest number from the nose ( 8 isolates). Fungi occurred more frequently in autumn and slightly less frequently in spring, and were isolated more frequently from women than from men.

Key words: yeast-like fungi, students, respiratory system, infection

\section{INTRODUCTION}

A continuous increase in fungal infections has been recorded in recent years (Baran 1998). It is believed that they affect ca. $40 \%$ of the world population (Maddin 1992). However, studies on the occurrence of yeast-like fungi mostly concentrate on compromised or hospitalised individuals under 20 or over 40 years of age (Biedunkiewicz 1999, 2001; Dynowska 1990, 1993, 1995) while yeastlike fungi can also occur as commensals in various ontocoenoses in healthy individuals (Batura-Gabryel, Firlik, Wieczorek 1994; Baran 1998; Richardson, War nock 1995). They colonise the oral cavity, mucous membranes, the skin, digestive system or genitourinary system. Plants and animals can also be reservoirs of fungi (Biegańska, Dworecka-Kaszak 2004; Dynowska 1995; Kurnatowska 1999). Therefore mycological studies were conducted on a group of healthy students of biology and veterinary medicine who come into direct contact with plants or animals, both living and dead, that may be colonised by fungi. 


\section{MATERIAL AND METHODS}

A group of 200 randomly selected students in the age bracket between 20 and 26 ( 76 men and 124 women) at the Faculty of Biology and the Faculty of Veterinary Medicine, Warmia and Mazury University in Olsztyn, was examined. Swabs form the oral cavity, the atrium of the nasal cavity and the throat were collected in autumn and spring in the period between 2002 and 2004. The subjects were generally healthy.

The subjects were asked to complete a questionnaire on the life environment, diet, use of substances, possible treatment with antibiotics, use of hormonal agents, and susceptibility to various types of infections.

Cultures were initially incubated on Sabouraud medium at $37^{\circ} \mathrm{C}$ for 72 hours and were examined according to the procedure used in mycological laboratories (Dynowska 1995; Kurnatowska 1995). Macroscopic features (colour, shape, surface structure, shine) of the isolated strains were analysed. The number of cultured colonies was used to assess the intensity of fungal growth in a five-point scale (0-4). Microculture incubation time on Nickerson agar, incubated at $37^{\circ} \mathrm{C}$, was prolonged to $144 \mathrm{~h}$ (Biedunkiewicz-Ziomek, Dynowska 2004). Microscopic features (shape and size of blastospores and chlamydospores, presence or absence of the pseudomycelium) were analysed next. Photographic documentation was made throughout the observations of macro- and microcultures.

Fungi were identified using the following studies: Kreger-van Rij (1984), Barnett, Payne and Yarrow (1990), Howard (2003), the atlas by De Hoog, Guarro and Figuerras (2000), studies by Dynowska (1995) and Kurnatowska (1995).

\section{RESULTS}

Nine species of yeast-like fungi belonging to 3 genera: Candida, Saccharomyces and Saccharomycopsis, were recorded in the subjects. Among these nine, seven species were isolated from the biologists. Nine mould species of 4 genera: Aspergillus, Penicillium, Scopulariopsis and Trichophyton, isolated in the students of veterinary medicine will be discussed in a separate study.

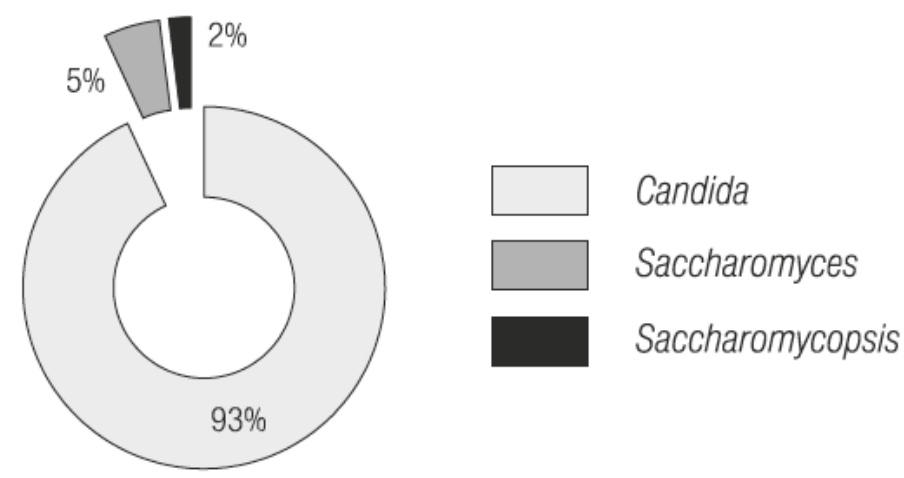

Fig. 1. Percentage participation of individual genera of yeast-like fungi in the students. 

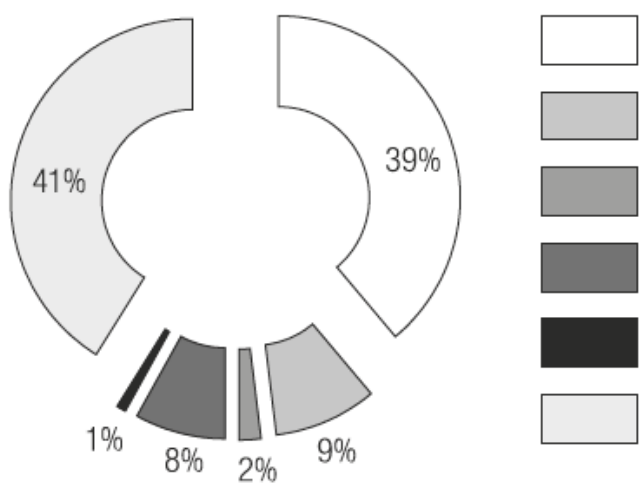

Candida albicans

Candida dubliniensis

Candida glabrata

Candida guilliermondii

Candida parapsilosis

Candida tropicalis

Fig. 2. Percentage participation of species of the genus Candida.

Candida tropicalis (83 isolates) and Candida albicans (77 isolates) were the most frequently isolated yeast-like fungi. Candida dubliniensis (18), C. guilliermondii (15) and Saccharomyces cerevisiae (10 isolates) were isolated less frequently. Saccharomycopsis capsularis (4), Candida glabrata (3) and C. parapsilosis (1) occurred sporadically (Figs 1, 2). The greatest number of fungi was isolated from the oral cavity (124 isolates), fewer from the throat ( 79 isolates), and the smallest number from the nose (8 isolates). Candida tropicalis (41.5\%) and Candida albicans (38.5\%) dominated in the ontocoenosis of the oral cavity. C. dubliniensis $(9 \%)$, C. guilliermondii $(7.5 \%)$ and Saccharomyces cerevisiae $(5 \%)$ were recorded less frequently. Candida dubliniensis $(1 \%)$, C. tropicalis $(0.5 \%)$, Candida glabrata $(0.5 \%)$ and Saccharomycopsis capsularis $(0.5 \%)$ were recorded in the nasal cavity in the autumn period, and $C$. tropicalis, $C$. guilliermondii and $C$. parapsilosis in the spring period. These were individual isolates that altogether constituted $1.5 \%$ of the total number of isolates. Candida tropicalis (total $17.5 \%$ ) and C. albicans (13.5\%) dominated in the throat both in spring and autumn. Other species constituted a slight percentage of the isolates (C. guilliermondii 3.5\%, C. dubliniensis $2.5 \%$, Saccharomycopsis capsularis $1 \%$, Saccharomyces cerevisiae $1 \%$, and C. glabrata $-0.5 \%$ ) (Tab. 1).

Fungal species occurred individually or in groups of two and, less frequently, three. Groups recurring most frequently were as follows: Candida tropicalis and $C$. guilliermondii, C. albicans and C.tropicalis, C. tropicalis and C.dubliniensis as well as C. albicans and C. dubliniensis.

Fungi occurred more frequently in autumn and slightly less frequently in spring. They were usually characterised by poor growth (113 isolates) (Tab. 2). Fungi were isolated more frequently from women (autumn $73.26 \%$, spring $63.41 \%$ ) than from men (autumn 26.74\%, spring 36.59\%) (Tab. 3).

The analysis of questionnaire data shows that the occurrence of fungi in the ontoceonoses studied was influenced by the use of substances (alcohol, cigarettes, coffee) (Tab. 4). The highest percentage of positive results was recorded in the subjects reporting excessive coffee consumption among the biology students (30\%), and cigarette smoking $(63.6 \%)$ and excessive alcohol consumption $(51.7 \%)$ among the veterinary students. Questionnaire data did not reveal any direct correlation between the occurrence of fungi and the type of diet. A slight increase in the number of positive 
A. Biedunkiewicz

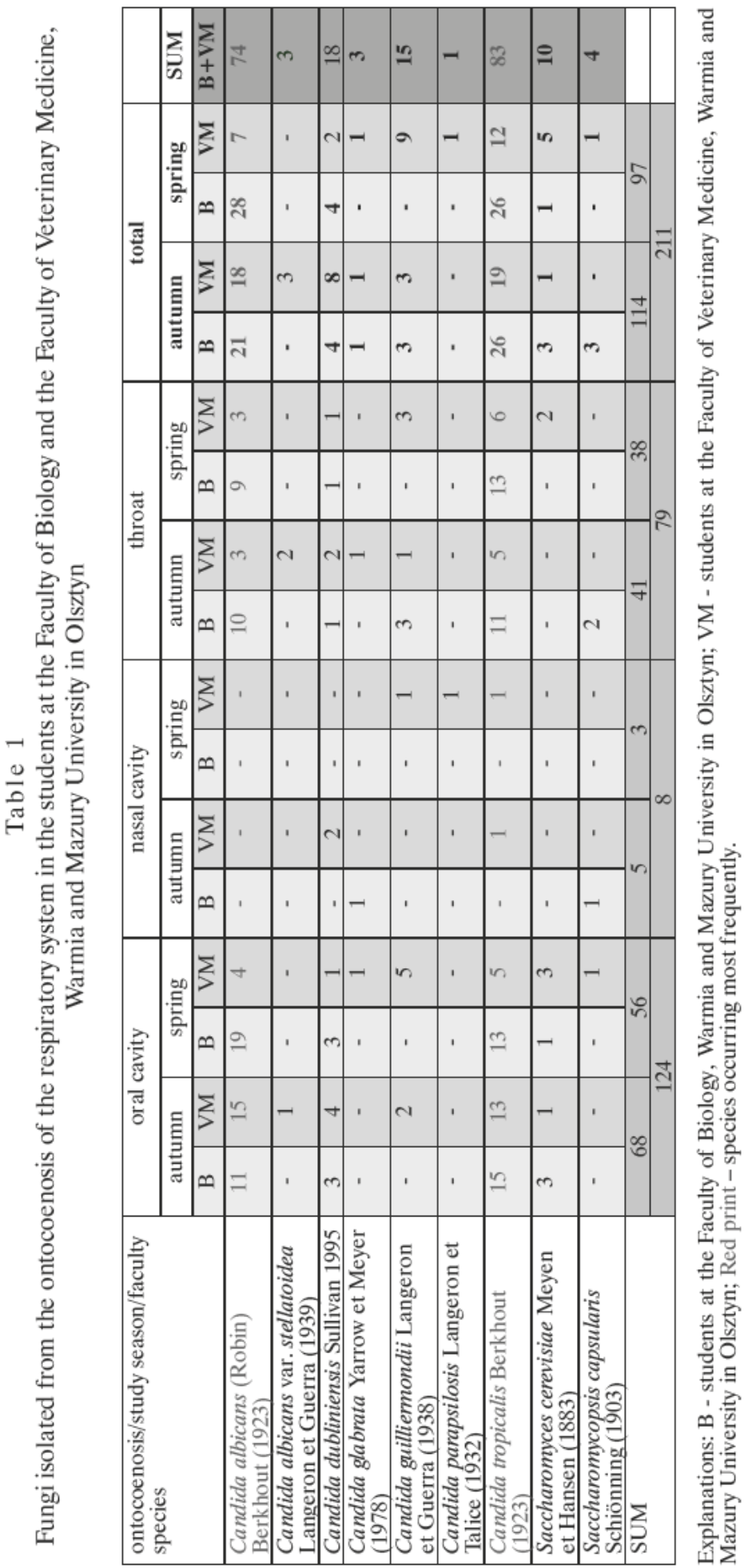


Table 2

Growth intensity of yeast-like fungi in autumn and spring

\begin{tabular}{|l|c|c|c|c|c|c|}
\hline $\begin{array}{r}\text { Study season/ } \\
\text { faculty }\end{array}$ & \multicolumn{7}{|c|}{ Number of ontocoenoses } \\
\cline { 2 - 7 } Growth intensity & autumn B & $\begin{array}{c}\text { autumn } \\
\text { VM }\end{array}$ & spring B & spring VM & $\begin{array}{c}\text { autumn } \\
\text { sum }\end{array}$ & $\begin{array}{c}\text { spring } \\
\text { sum }\end{array}$ \\
\hline Poor & 31 & 22 & 32 & 28 & 53 & 60 \\
\hline Moderate & 10 & 12 & 6 & 6 & 22 & 12 \\
\hline Abundant & 5 & 7 & 4 & 8 & 12 & 12 \\
\hline Very abundant & 3 & 7 & 2 & 6 & 10 & 8 \\
\hline Sum & 49 & 48 & 44 & 48 & 97 & 92 \\
\hline
\end{tabular}

Explanations: autumn B - number of isolates obtained from the students of biology in autumn; autumn $\mathrm{VM}$ - number of isolates obtained from the students of veterinary medicine in autumn

Table 3

Number of positive cultures in men and women in autumn and spring

\begin{tabular}{|c|c|c|c|c|c|c|c|c|c|c|c|c|}
\hline \multirow{3}{*}{ Sex $\begin{array}{r}\text { Study season/ } \\
\text { faculty }\end{array}$} & \multicolumn{12}{|c|}{ Number of positive cultures } \\
\hline & \multicolumn{4}{|c|}{ autumn } & \multicolumn{4}{|c|}{ spring } & \multicolumn{2}{|c|}{ autumn } & \multicolumn{2}{|c|}{ spring } \\
\hline & $\mathrm{B}$ & $\%$ & VM & $\%$ & B & $\%$ & VM & $\%$ & Sum & $\%$ & Sum & $\%$ \\
\hline Women & 36 & 73,47 & 27 & 71,05 & 27 & 61,36 & 25 & 65,79 & 63 & 73,26 & 52 & 63,41 \\
\hline Men & 13 & 26,91 & 11 & 28,95 & 17 & 38,64 & 13 & 34,21 & 23 & 26,74 & 30 & 36,59 \\
\hline Sum & 49 & 100 & 38 & 100 & 44 & 100 & 38 & 100 & 86 & 100 & 82 & 100 \\
\hline
\end{tabular}

Table 4

Occurrence of fungi in coffee drinkers, alcohol drinkers and smokers

\begin{tabular}{|l|c|c|}
\hline \multirow{2}{*}{ Type of substance } & \multicolumn{2}{|c|}{ Positive cultures (\%) } \\
\cline { 2 - 3 } & Biology & Veterinary medicine \\
\hline Alcohol & 12,0 & 25,0 \\
\hline Coffee & 30,0 & 51,7 \\
\hline Cigarettes & 19,5 & 63,6 \\
\hline
\end{tabular}

Table 5

Occurrence frequency of diseases preceding sampling

\begin{tabular}{|l|c|c|c|c|}
\hline \multicolumn{1}{|c|}{ disease } & rarely & often & very often & total \\
\hline throat diseases & 21 & 28 & 13 & 62 \\
\hline sinus diseases & 13 & 9 & 5 & 27 \\
\hline bronchial diseases & 22 & 5 & 2 & 29 \\
\hline pneumonia & 10 & - & 1 & 91 \\
\hline rhinitis & 29 & 42 & 20 & 16 \\
\hline ear infection & 11 & 4 & 1 & 3 \\
\hline asthma & 1 & 2 & - & 14 \\
\hline allergies & 5 & 6 & - & - \\
\hline tuberculosis & - & - & - & 7 \\
\hline diabetes & - & - & 1 & 9 \\
\hline vitamin deficiencies & 3 & 3 & - & 8 \\
\hline internal mycoses. & 5 & 4 & - & - \\
\hline cutaneous mycoses & 7 & 1 & - & 9 \\
\hline thyroid diseases & - & - & - & \\
\hline renal diseases & 8 & 1 & & \\
\hline
\end{tabular}


results was shown only among the subjects preferring animal foodstuffs (among the biology students: 79\%) and the subjects preferring dairy products (among the veterinary students: $46.9 \%$ ). Diets rich in carbohydrates were not reported. Questionnaire data also show that infections of the throat, bronchii and sinuses, and catarrhal conditions were the most frequent disorders preceding the examination (Tab. 5).

\section{DISCUSSION}

Yeast-like fungi that commonly occur in human environments colonise various ontocoenoses relatively easily. They enter the human body via the oral or nasal cavities when ingested or inhaled. The increase in fungal infections recorded worldwide is caused by the growing number of predisposing factors and the simultaneous decrease in natural immunity of healthy individuals (Ghannoum, Abu-Elteen 1990; Szy maniak et al. 2005). As a result, permeability of the epithelium changes, allowing fungi to enter the body and penetrate the tissues (Dynowska, Biedunkiewicz, Sucharzewska 2002).

Fungi isolated in such portals of infection as the oral cavity can be causal agents of the development of fungal infections although they do not have to. Kurnatowski and Raczyńska-Witońska (2004) recorded fungi in the oral cavity of $65.6 \%$ of the individuals studied. They detected: Candida albicans (43.8\%), C. tropicalis (15.7\%), C. krusei (9.7\%), C. kefyr (9.7\%), C. guilliermondii (4.9\%), C. parapsilosis (4.3\%), C. glabrata (5.9\%) and Geotrichum candidum (5.9).

Yeast-like fungi, mostly Candida albicans, are recorded asymptomatically in the oral cavity in 40-60\% of individuals (Kałowski 1964). Darwazeh, Al-Refai and Al-Mojaiwel (2001) believe that fungi of the genus Candida are part of the normal, commensal mycoflora of the oral cavity, present in 30-70\% of generally healthy individuals. In mass studies, Kowszyk-Gindifer and Sobiczewski (1986) recorded fungal infections in the oral cavity in $44 \%$ of students and $46 \%$ of individuals across various occupational groups. In the studies conducted by Kurnatowska (2003) on individuals suffering from conditions of the oral cavity, as many as 6 species of the genus Candida were isolated: C. albicans -146 strains (74.6\%), C. tropicalis - 18 (9.2\%), C. krusei-10 (5.1\%), C. guilliermondii-6 (3.1\%), C. famata $-5(2.6 \%)$, C. zeylanoides $-2(1.0 \%)$. Candida albicans was also the most frequently recorded fungus in studies by Majewska et al (2000) who additionally observed a high frequency of $C$. glabrata, $C$. parapsilosis and $C$. tropicalis. The differences in the frequency of occurrence of these fungi may be related to the season, time of day, type of diet, oral hygiene, as well as sampling and test methods.

Candida tropicalis was one of the most frequently isolated species of yeast-like fungi: $52 \%$ among the biology students and $31 \%$ among the veterinary students. This finding is corroborated in studies by Ejdys and Dy nows ka(2004) conducted on a group of healthy children. The majority of species recorded in the present study are classified as biosafety level 2 (BSL2): they may cause severe, opportunistic infections in immunocompromised individuals (de Hoog 1996).

The occurrence of fungi in the nasal cavity or paranasal sinuses in healthy individuals is reported very rarely. Their presence in these ontocoenoses is mostly related to chronic inflammatory conditions of mucous membranes caused by bacteria, 
allergy, asthma, polyps or deviated nasal septum (Hofman, Skrobisz and Hofman 2004; Jankowska-Konsur, Preś and Baran 2005).

Kowszyk-Gindifer and Sobiczewski (1986) recorded fungi in $69 \%$ of the students examined by them. Kurnatowski and Raczyńska-Witońska (2004) report that fungi occur on the mucous membrane of the throat in $24.5-53.6 \%$ of patients suffering from chronic pharyngitis, in ca. $2 / 3$ of conditions of palatine tonsils and only in $1 / 5$ of those of the pharyngeal tonsil.

Fungi are recorded in one or a few ontocoenoses in the same person. The present results correspond to those obtained by Ejdys and Dynowska (2004), who observed this correlation in a group of healthy children in their study on environmental preconditioning of fungal infections.

The occurrence of potentially pathogenic fungi in individuals who consider themselves to be generally healthy may be related to a decrease in their immunity. Sources of fungal infection should thus be considered. As reported in the literature, generalised or multifocal infections caused by fungi of the genus Candida are mostly endogenous, which does not exclude their exogenous origin (Biegańska, Dworecka-Kaszak 2003).

Animals can also be a source of infection. Students of biology and veterinary medicine come into direct contact with animals, both healthy and ill, during classes. Some, especially veterinary students, may work in veterinary clinics where they deal with animals that are living or dead (in anatomy laboratories). The occurrence of fungi of the genus Candida is recorded in many animal species and diseases caused by these fungi are not rare. The literature published so far does not show whether interspecific transmission of Candida infection is possible and what the particular character of biotypes of individual species of these yeast-like fungi in relation to the host is. Biegańska and Dworecka-Kaszak (2003) examined 230 Candida strains isolated from animals between 1998 and 2002. They noticed an increase in the number of infections caused by these fungi in animals, and the number of all positive results exceeded $15 \%$ in 2002 . This means that Candida sp. is an important aetiological factor of infection, also in animals. Candidiases were detected mostly in dogs, horses and birds, and affected the respiratory system (nose and throat), reproductive system, skin and its products (Biegańska, Dworecka-Kaszak 2003). As can be seen, no great differences exist in specific places of isolation of Candida sp. between people and animals.

Zoonoses may in many cases be treated as occupational diseases. Particularly exposed occupational groups include veterinarians, veterinary technicians, students of these subjects, technicians specialising in animal husbandry, animal farmers, staff in vivaria, zoological gardens, abattoirs and utilisation plants, etc. (Dutkiewicz, Jabłoński 1989; Fijałkowska 1983).

Isolating potentially pathogenic fungi in healthy individuals indicates decreasing immunity. Commensal fungi can become causal agents of a number of diseases. This shows the need for a greater emphasis on mycological tests and analyses, also in outpatients, to increase immunoprevention or, directly, antifungal prevention (Mochon, Cutler 2005). 


\section{CONCLUSIONS}

1. Nine species of yeast-like fungi belonging to 3 genera: Candida, Saccharomyces and Saccharomycopsis, were recorded in healthy students. Candida tropicalis (83 isolates) and Candida albicans (77 isolates) were the most frequently isolated fungi.

2. The greatest number of fungi were isolated from the oral cavity (124 isolates), fewer from the throat (79 isolates), and the smallest number from the nose ( 8 isolates).

3. The greatest percentage of positive results was recorded in the subjects reporting excessive coffee consumption among the biology students (30\%), and cigarette smoking $(63.6 \%)$ and excessive alcohol consumption (51.7\%) among the veterinary students.

4. Isolating potentially pathogenic fungi in healthy individuals in the 20-30 age bracket indicates their decreasing immunity. It shows the need for a greater emphasis on mycological testing to increase antifungal prevention and help identify carriers of fungi among students.

\section{REFERENCES}

B a ran E. 1998. Zarys mikologii lekarskiej. VOLUMED. Wrocław.

Barnett J. A., Payne R. W., Yarrow D. 1990. Yeasts: Characteristics and identification. Cambridge Univ. Press.

Batura-Gabryel H., Firlik M., Wieczorek U. 1994. Ocena występowania zakażenia grzybiczego u chorych z rakiem płuc. Med. Dośw. Mikrobiol. 46: 77-81.

Bie dunkiewicz A. 1999. Analiza mikologiczna materiału bronchoskopowego. Mikol. Lek. 6 (1): 33-40.

Bie dunkiewicz A. 2001. Dynamics of human respiratory system mycoflora. Acta Mycol. 36 (2): 211239.

Biedunkiewicz-Ziomek A., Dynowska M. 2004. Candida dubliniensis Sullivan et al., a new species in the human respiratory system. Acta Mycol. 39 (1): 7-12.

Bieg a ńsk a M., Dw or e ck a-Ka szak B. 2003. Charakterystyka szczepów Candida sp. izolowanych w latach 2001-2002 od zwierząt. Mikol. Lek.10 (4): 275-283.

Darwazeh A. M., Al-Refai S., Al-Mojaiwel S. 2001. Isolation of Candida species from the oral cavity and fingertips of complete denture wearers. The Journal of Prosthetic Dentistry 86 (4): 420423.

De Hoog G. S. 1996. Risk assessment of fungi reported from humans and animals. Mycoses 39: 407417.

De Hoog G. S., Guarro J., Figuerras M. J. 2000. Atlas of clinical fungi. Utrecht, the Netherlands, Reus, Spain.

Dutkiewicz J., Jabłońs s i J. 1989. Biologiczne szkodliwości zawodowe. PZWL. Warszawa.

Dyn owsk a M. 1990. Występowanie grzybów z rodzaju Candida w układzie oddechowym mieszkańców województwa olsztyńskiego. Acta Mycol. 26 (1): 99-107.

Dynowska M. 1993. Observations concerning the appearance of yeasts in human respiratory system. Acta Mycol. 28 (2): 147-150.

Dyn owska M. 1995. Drożdże i grzyby drożdżopodobne jako czynniki patogenne i bioindykatory ekosystemów wodnych. Studia i Materiały WSP 77. Olsztyn.

Dynowska M., Biedunkiewicz A. 1999. Presence of Saccharomycopsis capsularis in the human respiratory system. Acta Mycol. 34 (2): 281-287.

Dy now sk a M., Biedunkiewicz A., Sucharzewska E. 2002. Participation of yeast-like fungi in respiratory system diseases, tuberculosis and neoplasms. Acta Mycol. 37 (1/2): 117-122.

Ejdys E., Dynowska M. 2004. Environmental preconditioning of the fungal infection of children. Mikol. Lek. 11 (1): 9-13.

Fijałk ows k a W. 1983. Czym mogą zarazić nas zwierzęta? PWRiL. Warszawa.

Ghannoum M. A., Abu-Elteen K. M. 1990. Pathogenicity determinants of Candida. Mycoses 33: 265-282. 
Hofman T., Skrobisz W., Hofman A. 2004. Ocena skuteczności leczenia flukonazolem chorych na przewlekłe zapalenie zatok przynosowych. Mikol. Lek. 11 (4): 297-301.

How ard D. H. 2003. Pathogenic fungi in humans and animals. Marcel Dekker Inc., New York, Basel.

Jankowska-Konsur A., Preś K., B aran E. 2005. Grzybicze zakażenia nosa i zatok przynosowych. Mikol. Lek. 12 (2): 133:136.

Kałows ki M. 1964. Występowanie drożdżaków w zdrowej jamie ustnej człowieka. Czas. Stomatol. 17: $427-432$.

Kows zyk-Gindifer Z., Sobiczewski W. 1986. Grzybice i sposoby ich zwalczania. PZWL.

Kreger-van Rij N. J. W. 1984. The yeasts: a taxonomy study. Third revision and enlarged edition. Els. Sci. Publ. Amsterdam.

Kurnat ows ka A. 1995. Wybrane zagadnienia z mikologii medycznej. Promedi. Łódź.

Kurnat ow ska A. 1999. Ekologia. Jej związki z różnymi dziedzinami wiedzy. PWN. Warszawa.

Kurnat ows k a A. J. 2003. Występowanie grzybów w ontocenozie jamy ustnej a zmiany błony śluzowej. Mikol. Lek. 10 (4): 295-298.

Ku rna tows ki P., Ra czyń s ka -Wi toń s ka G. 2004. Grzyby jako czynnik etiologiczny chorób górnych dróg oddechowych. Wiad. Parazytol., 50 (2): 157-162.

Macur a A. B. 1987. Przyleganie grzybów drożdżopodobnych do komórek ssaków. Post. Mikrobiol. 26: 337-351.

Maddin S. 1992. What is the therapeutics? J. Europ. Acad. Dermatol. Venerol. 1: 31-35.

Majewska A., Sozańska Z., Kasiak M., Czajczyńska-Waszkiewicz A. 2000. Występowanie grzybów drożdżopodobnych w jamie ustnej a intensywność próchnicy zębów. Mikol. Lek. 7 (2): $71-75$.

Mochon A. B., Cutle r J. E. 2005. Prospects of vaccines for medically important fungi. Medical Mycology 43: 97-115.

Rabczyński J., Dzięgiel P., Ziółkowski P. 1998. Uogólniona drożdżyca u noworodków - obraz patomorfologiczny. Mikol. Lek. 5 (2): 105-109.

Richardson M. D., Warnock D. W. 1995. Grzybice - rozpoznawanie i leczenie. PWN. Warszawa.

S a monis G. 2004. Gut: Portal of entry of fungi in the immunocompromised hosts. Mikol. Lek.11 (2): 105-107.

Sysło J., Ma cu ra A. B. 1998. Badania nad niektórymi determinantami patogenności u grzybów z rodzaju Candida. Mikol. Lek. 5 (3): 149-155.

Szymaniak L., Wojciechowska-Koszko I., Klimowicz B., Giedrys-Kalemba S. 2005. Non-lipophilic yeast flora from selected body sites in healthy subjects. Mikol. Lek. 12 (4): 291-295.

\section{Grzyby drożdżopodobne izolowane od studentów}

\section{Streszczenie}

W pracy przeanalizowano występowanie grzybów drożdżopodobnych w głównych wrotach zakażenia układu oddechowego, dwustu losowo wybranych studentów biologii i medycyny weterynaryjnej, mających w trakcie studiów bezpośredni kontakt z roślinami i zwierzętami, które mogą być zasiedlane przez grzyby z różnych grup systematycznych.

W przeprowadzonych badaniach u wszystkich studentów stwierdzono 9 gatunków grzybów drożdżopodobnych, z czego 7 u biologów. Najczęściej izolowano: Candida tropicalis (83 izolaty) i Candida albicans (77 izolatów). Najwięcej grzybów wyizolowano z jamy ustnej (124 izolaty), mniej z gardła (79), najmniej z nosa (8). Grzyby częściej występowały jesienią, nieco rzadziej wiosną, u kobiet niż u mężczyzn. Ogółem najwyższy odsetek wyników dodatnich odnotowano u osób zgłaszających nadużywanie kawy $(30 \%)$, palących papierosy $(63,6 \%)$ i nadużywających alkoholu $(51,7 \%)$.

Izolowanie grzybów potencjalnie chorobotwórczych od zdrowych studentów wskazuje na obniżony stan ich odporności i skłania do położenia większego nacisku na analizy i badania mikologiczne w celu zwiększenia profilaktyki przeciwgrzybicznej w grupach osób zdrowych. 